\title{
PELESTARIAN RUMAH DINAS PT KAI AMBARAWA
}

\author{
Kukuh Dwi Prasetyo*, Atik Suprapti, Erni Setyowati
}

*) Corresponding author email : kukuhdwi_prasetyo@ymail.com

Departemen Arsitektur, Fakultas Teknik, Universitas Diponegoro, Semarang - Indonesia

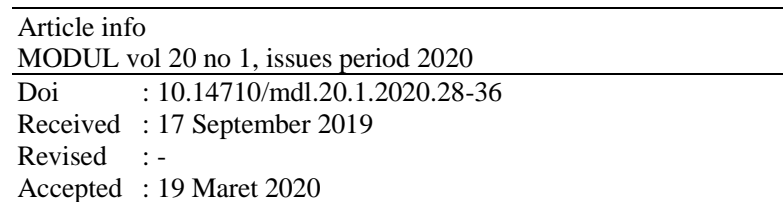

\section{Abstrak}

Studi ini bertujuan untuk mengidentifikasi dan menganalisis karakter bangunan Rumah Dinas PT KAI Ambarawa yang meliputi karakter spasial, visual, dan struktural bangunan, menganalisis dan menentukan strategi arahan pelestarian bangunan Rumah Dinas PT KAI Ambarawa. Metode analisis data yang digunakan pada studi ini, yaitu metode deskriptif analisis, evaluatif, dan development. Hasil dari analisis tentang karakter visual bangunan rumah dinas PT KAI Ambarawa ini, di dominasi bentukan geometri. Ciri visual pada bangunan rumah memiliki beberapa bentuk geometri, antara lain persegi panjang, segitiga dan jajaran genjang. Terdapat tiga tingkatan ruang pada bangunan rumah dinas, yaitu ruang utama sebagai pusat aktivitas, ruang selasar sebagai akses menuju keruang service yang menjadi ruang ketiga. Penggunaan elemen- elemen bangunan dengan ukuran besar dan ornament-ornamen menggambarkan bangunan rumah dinas ini merupakan bangunan peninggalan kolonial Belanda. Ciri spasial bangunan, terjadi perubahan, yaitu penambahan beberapa ruang dengan alasan memenuhi kebutuhan ruang pihak rumah sakit. Ciri struktural terlihat pada bangunan asli peninggalan kolonial yang sampai saat ini menggunakan dinding dengan ketebalan satu bata dan penggunaan modul struktur serta konstruksi atap pada bangunan rumah dinas dibagi menjadi tiga macam, antara lain konstruksi atap limasan, pelana dan atap sandar / datar.. Arahan pelestarian bangunan untuk rumah dinas PT KAI Ambarawa ini diklasifikasikan berdasarkan tiga kelas, yaitu elemen bangunan potensial rendah, sedang, dan tinggi.

Kata Kunci: Museum Kereta Api Ambarawa; Rumah Dinas; Pelestarian

\begin{abstract}
Abstrak
This study aims to identify and to analyze the characteristics of PT KAI Ambarawa official residence including the spatial, visual, and structural characteristics of the buildings, and to analyze and to determine the preservation directives for the PT KAI Ambarawa official residence. The methods used in this study are descriptive analysis, evaluative, and development methods. The results of this study show that the visual character of PT KAI Ambarawa official residence is dominated by the geometric formations. The visual characteristics of the official residence have several geometric shapes, including rectangles, triangles, and parallelograms. There are three levels of space in this official residence, which are the main room as the center of activity, the lobby area as the access to the service room, which is also as the third room. The use of the building elements within the large size and the ornaments depict that the building of this official residence is a Dutch colonial heritage building. In the spatial characteristics of buildings, there are some changes to the building, namely the addition of some space because it meets the space requirements of the hospital. The structural characteristics can be seen in the original colonial heritage buildings which until now use a brick wall thickness and the use of structural modules and roof construction in the official building that is divided into three types: construction of pyramid, saddle and flat roofs. The building preservation directives for PT KAI Ambarawa official residence are classified into three classes, namely low, medium and high potential building elements.
\end{abstract}

Keywords: Ambarawa Railway Museum; Official Residence; Preservation

\section{PENDAHULUAN}

Rumah dinas PT. KAI Ambarawa yang terletak di kawasan Museum Kereta Api Ambarawa merupakan bangunan bersejarah yang dibangun di awal abad 19 
atau tahun 1900, bersamaan dengan di bangunannya jalur kereta api di wilayah Ambarawa hingga Secang. Bangunan cagar budaya yang memiliki nilai sejarah yang tinggi ini merupakan saksi bisu bagaimana perkembangan sejarah Ambarawa. Hingga kini keberadaan rumah rumah dinas ini ada yang masih terawat dan difungsikan sebagai rumah dinas Pegawai PT KAI yang bekerja di Museum KA Ambarawa, ada juga yang saat disewakan turun menurun ke keluarga Pegawai PT KAI yang dahulu bekerja di Stasiun Ambarawa. Bangunan rumah dinas ini tidak semua nya dalam kondisi sama seperti aslinya, ada rumah yang sudah mengalami penambahan ruang bangunan dan ada 4 unit rumah dinas yang diratakan karena adanya renovasi dan pengembangan museum Kereta Api Ambarawa Wibowo, Bakti. "9 Bangunan di Sekitar Museum KA Ambarawa Ditertibkan." Jogja.Tribunnews.com. 10 September 2017.

Sangat disayangkan warisan sejarah yang memiliki prospek yang cerah di bidang wisata sejarah kota Ambarawa dan Indonesia ini dihancurkan dan dibiarkan tanpa ada pemeliharaan serta pengelolaan yang maksimal dari Pemerintah dan pihak Museum Kereta Api Ambarawa. Padahal menghancurkan bangunan kuno bersejarah sama halnya dengan menghapuskan salah satu cermin untuk mengenali sejarah dan tradisi masa lalu. Seperti yang dikemukakan oleh Budihardjo (1985), bahwa arsitektur dan kota di Indonesia saat ini banyak yang menderita sesak nafas. Dengan hilangnya bangunan kuno bersejarah, lenyaplah pula bagian sejarah dari suatu tempat yang sebenarnya telah menciptakan suatu identitas tersendiri, sehingga menimbulkan erosi identitas budaya (Sidharta dan Budhihardjo, 1989). Oleh karena itu, konservasi bangunan bersejarah sangat dibutuhkan agar tetap bisa menjaga cagar budaya yang sudah diwariskan oleh para pendahulu kita kemudian menjadikannya local wisdom dan identitas dari kota Ambarawa.

Dalam menganalisa penelitian bangunan rumah dinas PT. KAI Ambarawa ini metode penelitian yang digunakan adalah metode analisis data dengan pendekatan metode deskriptif analisis, evaluatif dan developmen. Diharapkan hasil dari penelitian menjadi dasar dalam menentukan arahan strategi dalam upaya pelestarian bangunan rumah dinas PT KAI Ambarawa dan mampu menjadikan Rumah dinas PT KAI Ambarawa ini sebagai aset penting dan local wisdom bagi PT KAI dan Kota Ambarawa.

\section{KAJIAN TEORI}

\section{Pengertian Rumah Dinas}

Definisi dari rumah negara dapat dilihat dalam Peraturan Pemerintah Nomor 40 Tahun 1994 juga Peraturan Pemerintah Nomor 31 Tahun 2005 tentang Rumah Negara, adalah bangunan yang dimiliki negara dan berfungsi sebagai tempat tinggal atau hunian dan sarana pembinaan keluarga serta menunjang pelaksanaan tugas Pejabat dan/atau Pegawai Negeri.

\section{Gambaran Umum PT. KAI}

PT Kereta Api Indonesia (Persero) adalah Badan Usaha Milik Negara Indonesia yang menyelenggarakan jasa angkutan kereta api. Layanan PT Kereta Api Indonesia (Persero) meliputi angkutan penumpang dan barang (Wikipedia, 2013).

Gambaran Umum Rumah Dinas PT KAI Ambarawa

Rumah dinas KAI Ambarawa yang terletak di kawasan stasiun Ambarawa. Dibangun di awal abad 19 atau tahun 1900, bersamaan dengan di bangunannya jalur kereta api di wilayah Ambarawa hingga Secang. Jalur ini merupakan salah satu jalur kereta api termahal yang pernah dibuat oleh perusahaan kereta api Hindia Belanda (Nederlands Indische Spoorweg Maatschappij). Karena menghabiskan biaya sekitar 390.000 Gulden dan harus mengerahkan 3000 pekerja setiap hari untuk mengerjakannya.

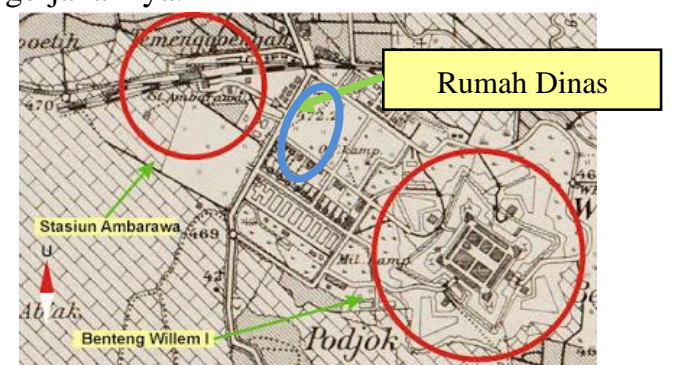

Gambar 1. Lokasi Rumah Dinas PT. KAI pada Peta Tahun 1909

Sebagai bangunan stasiun berukuran cukup besar, tentu Stasiun Ambarawa memiliki fasilitas bangunan rumah dinas untuk tempat tinggal para pegawai stasiun. Stasiun Ambarawa sendiri memiliki 6 buah rumah dinas. Rumah dinas ini berada di sebelah Stasiun. Lokasinya yang tidak terlalu jauh sangat memudahkan mobilitas para pegawai dari tempat tinggal ke tempat kerja.
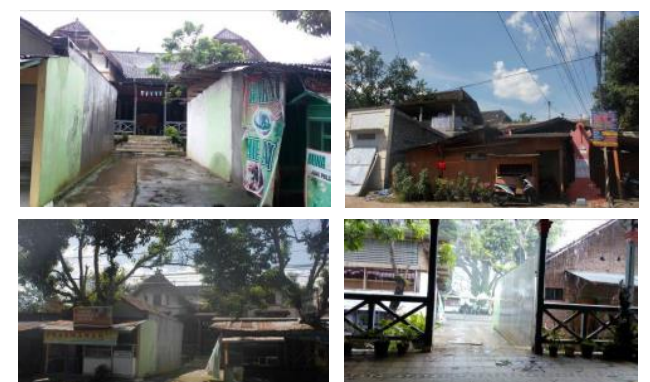

Gambar 2. Kondisi Rumah Dinas PT KAI Ambarawa

\section{HASIL PENELITIAN DAN PEMBAHASAN}

Rumah dinas PT KAI berada di Kawasan Museum Kereta Api Ambarawa di jalan Pemuda, Ambarawa, Jawa Tengah. Peta wilayah Kota Ambarawa pada tahun 1909 diatas menunjukan letak rumah dinas 
PT. KAI dengan tiap petak memiliki kombinasi halaman dan hanya terdapat rumah dinas PT KAI saja yang berdiri dikawasan Stasiun Ambarawa.

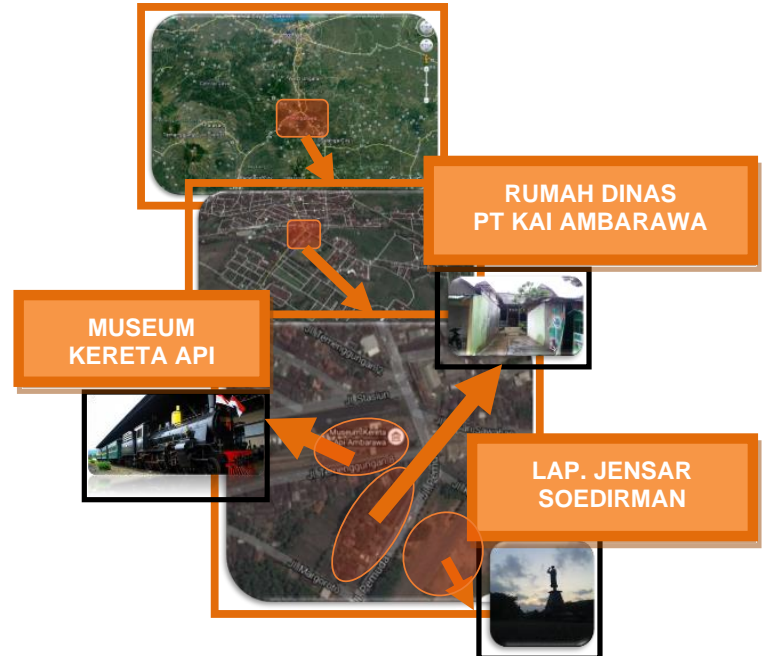

Gambar 3. Rumah Dinas PT. KAI Ambarawa Tahun 2015

\section{Metode Deskriptif Analisis \\ Karakter Spasial Bangunan Orientasi Bangunan}

Bangunan rumah dinas ini berorientasi menghadap ke arah Tenggara yaitu menghadap Jalan Ambarawa dan Lapangan Panglima Besar Jenderal Soedirman Ambarawa.

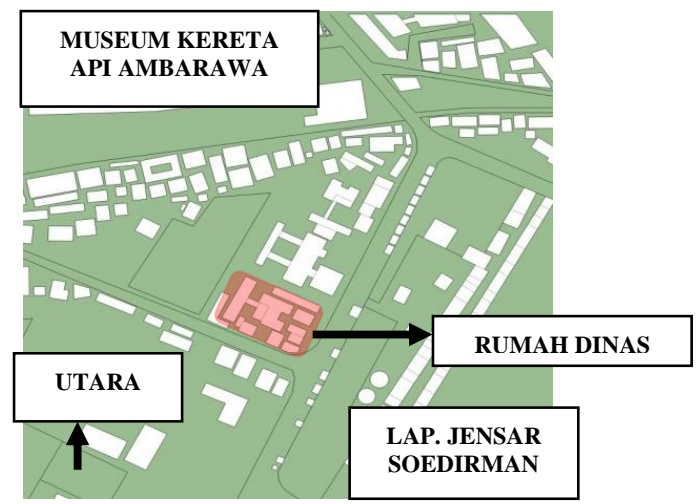

Gambar 4. Siteplan Wilayah Sekitar Rumah Dinas

\section{Organisasi ruang}

Ruang pada bangunan rumah dinas ini dibagi menjadi 3 yaitu area ruang utama, selasar atau penghubung dan ruang service.

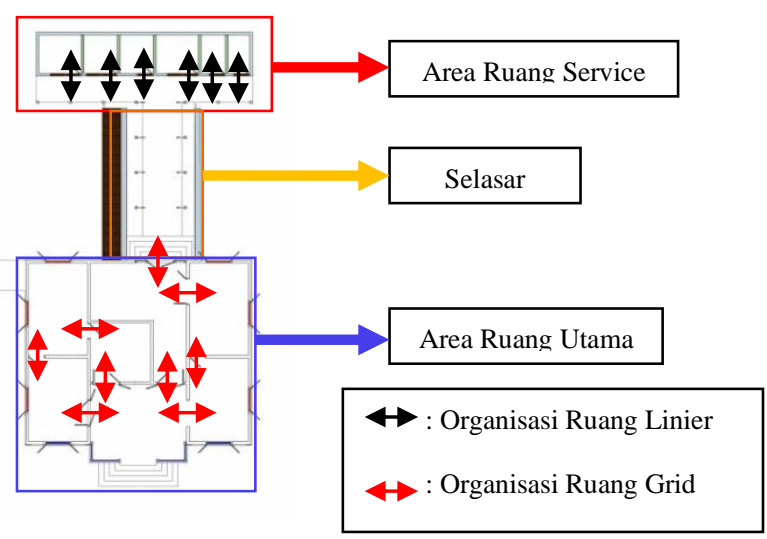

Gambar 5. Organisasi Ruang Rumah Dinas

Penataan ruang pada bangunan rumah dinas ini yaitu mengunakan pola ruang linier pada area ruang service yaitu ruang ruang yang dihubungkan oleh satu ruang panjang serta pola ruang grid pada bangunan utamanya.

Sirkulasi masuk pada bangunan menggunakan pintu utama yang terletak area teras depan yang menjadi pemisah antara ruang luar dan dalam. Bangunan rumah dinas ini terdiri dari satu ruangan teras yang berukuran besar, kemudian dihubungkan dengan ruang-ruang berukuran lebih kecil namun bentuknya serupa. Ruangruang pada bangunan saling menghubungan dan memiliki akses langsung tanpa perlu ke luar ruangan, dengan adanya teras yang memiliki fungsi sebagai jalur sirkulasi dan ruang transisi sebelum memasuki ruang asli dan ruang selasar yang menhubungkan bangunan utama dengan bangunan service. Perubahan fungsi awal ruang yang akhirnya berdampak adanya penambahan ruang dan bangunan baru, sehingga organisasi ruang yang ada berubah menjadi berkelompok yang disebabkan adanya perubahan fungsi dan penambahan penghuni.

\section{Karakter visual bangunan Massa Bangunan}

Bangunan rumah dinas ini memiliki beberapa bentuk geometri, antara lain persegi panjang, segitiga dan jajaran genjang. Terdapat tiga tingkatan ruang pada bangunan rumah dinas, yaitu ruang utama sebagai pusat aktivitas, ruang selasar sebagai akses menuju keruang service yang menjadi ruang ketiga.

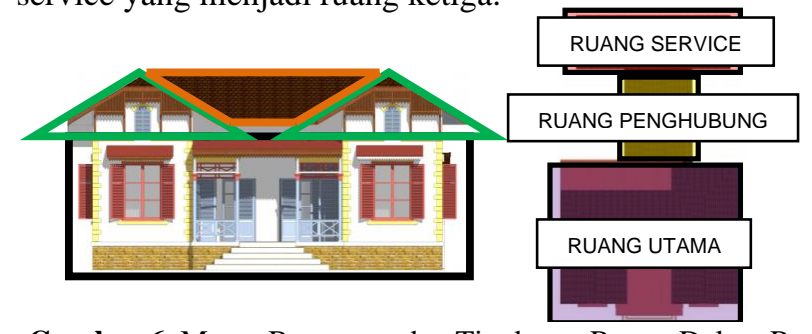

Gambar 6. Massa Bangunan dan Tingkatan Ruang Dalam Rumah Dinas 


\section{Gaya Bangunan}

Rumah dinas PT KAI Ambarawa ini dibangun pada abad ke 18 dan 19 yang bergaya arsitektur "Indische Empire Style".

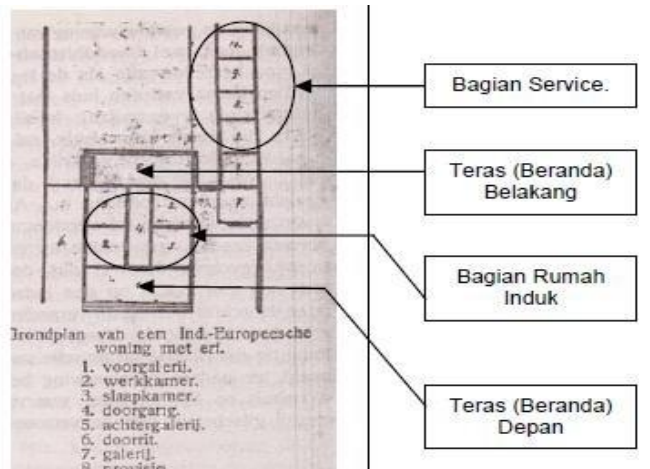

Gambar 7. Contoh Tipologi Denah Bangunan Gaya "Indische Empire"

Ciri khasnya adalah adanya teras depan, bangunan utama di tengah sedangkan bangunan service terpisah yang dipisahkan oleh selasar. Tampak bangunan berbentuk simetri penuh. Gaya bangunan ini berkembang abad 18 dan 19.
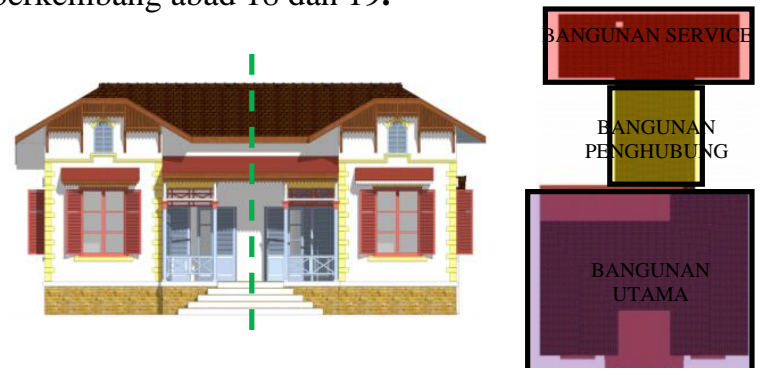

Gambar 8. Tampak Depan dan Atas Bangunan Berbentuk Simetri

\section{Elemen Fasade dan Ruang Dalam Bangunan}

Rumah dinas ini memiliki bentuk fasade tampak depan dan belakang yang simetris. Elemen fasade bangunan dan elemen ruang dalam terdiri dari atap, dinding, pintu, jendela, lantai dan langit-langit (plafond).
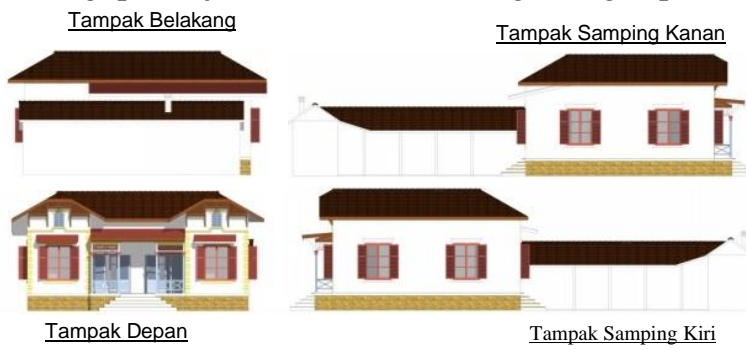

Gambar 9. Tampak Bangunan Rumah Dinas
Atap

- Atap rumah type 1 ini memiliki kemiringan lebih dari $30^{\circ}$.

- Bentuk atap adalah kombinasi atap hipped gable yang disangga oleh Deltis ( konsol penyangga atap tritisan ) dengan limasan untuk bangunan utama, atap datar / sandar pada bagian beranda rumah yang disangga dengan kolom kayu dan atap pelana untuk bangunan selasar dan bangunan service dibelakangnya.

- Terdapat hiasan pada Deltis ( konsol penyangga atap tritisan ) yang terdiri dari ornament papan kayu yang disusun vertical dan pada listplank atap sandar dan tritisan atas jendela depan rumah dinas.

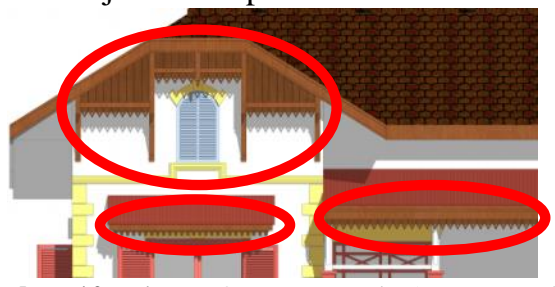

Gambar 10. Hiasan Ornamen pada Atap Rumah Dinas

\section{Dinding}

- Dinding eksterior dan interior bangunan rumah dinas type 1 ini didominasi warna putih.

- Dinding rumah type 1 ini memiliki ketebalan 1 bata atau sekitar $25 \mathrm{~cm}$.

- Terdapat hiasan dinding berupa penebalan dinding pada bagian atas pintu, jendela dan bagian bagian depan rumah dinas.

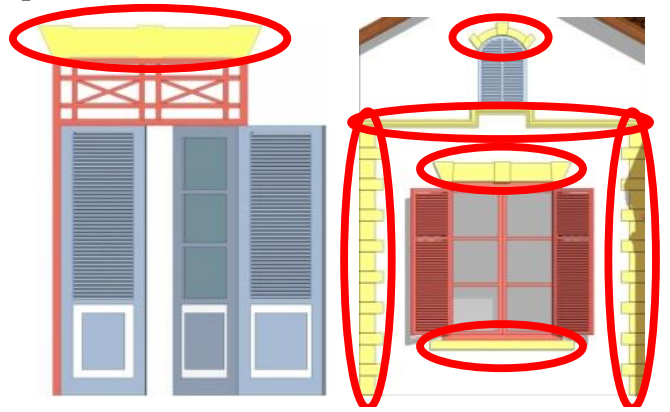

Gambar 11. Penebalan pada dinding Rumah Dinas

- Terdapat penebalan dinding dengan tebal sekitar 15 $\mathrm{cm}$ dan lebar $30 \mathrm{~cm}$ yang mengelilingi bangunan sebagai pembatas antara lantai rumah dengan permukaan tanah, area antara penebalan dan permukaan tanah ini dihiasi oleh pasangan bata yang disusun horizontal.

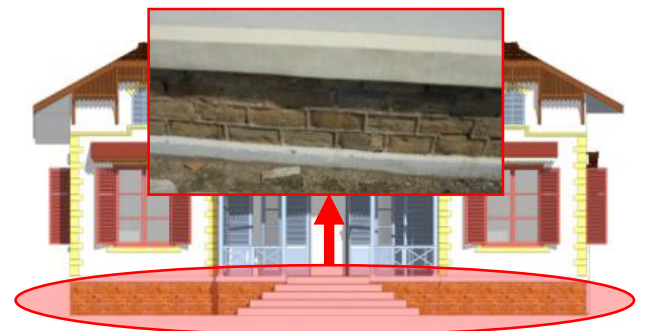

Gambar 12. Penebalan dinding dan pasangan batu bata 
Pintu dan Jendela

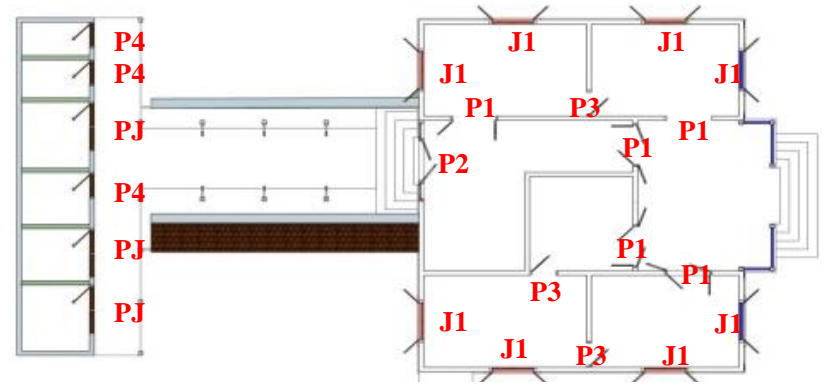

Gambar 13. Denah Pintu dan Jendela Rumah Dinas

\section{Pintu}

Pintu di rumah dinas KAI ada 5 Jenis, antara lain : Pintu P1

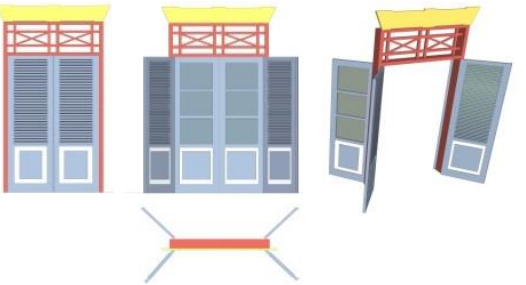

Gambar 14. Pintu P1

Pintu dengan 2 bukaan, dalam dengan panel kaca dan bagian luar dengan model Jalousie Window atau panel krepyak, yaitu jendela yang memiliki pelat-pelat penjang horizontal (sirip) dari kayu yang tersusun rapat. Selain itu bukaan pintu ini lebar, memudahkan untuk akses keluar masuk, penghawaan dan pencahayaan.

Pintu P2
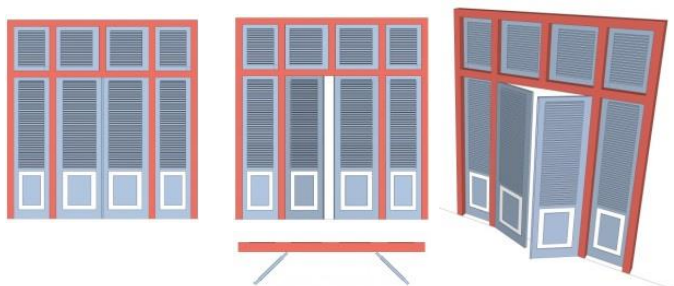

Gambar 15. Pintu P2

Pintu dengan model Jalousie Window, memiliki 2 buah daun pintu mati yang tidak bisa dibuka dengan model yang sama dengan daun pintu, lubang ventilasi angin juga memiliki model yang sama. Hal ini dimaksudkan agar penghawaan udara tetap baik melalui pintu P2.

\section{Pintu P3}

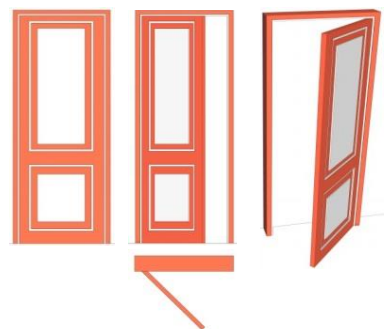

Gambar 16. Pintu P3
Pintu P3 merupakan pintu dengan satu daun pintu yang berupa panel kayu.

\section{Pintu P4}

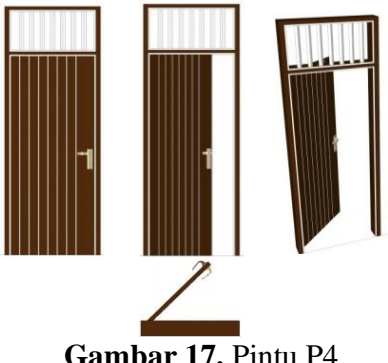

Pintu P4 adalah daun pintu biasa dengan hiasan coakan garis-garis vertical pada daun pintunya, lubang ventilasi diatasnya ditutup dengan kayu persegi yang disusun vertical.

Pintu PJ
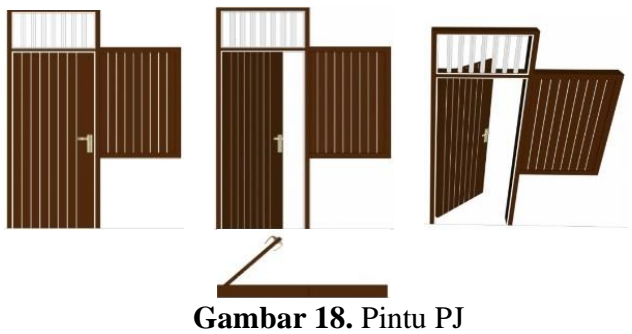

Pintu PJ adalah daun pintu biasa dengan tambahan satu jendela dengan hiasan coakan garis-garis vertical pada daun pintu dan jendelanya, lubang ventilasi diatasnya ditutup dengan kayu persegi yang disusun vertical.

Jendela

Jendela J1
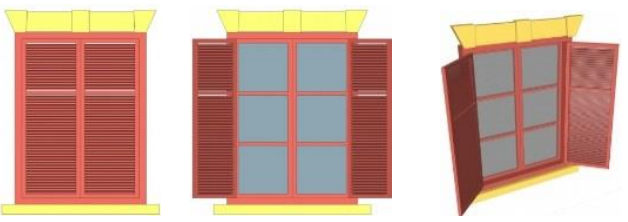

Gambar 19. Jendela J1

Jendela J1 adalah jendela dengan 2 bukaan, didalam dengan panel kaca dan bagian luar dengan model Jalousie Window atau panel krepyak, yaitu jendela yang memiliki pelat-pelat penjang horizontal (sirip) dari kayu yang tersusun rapat. Selain itu bukaan pintu ini cukup lebar, memudahkan untuk akses keluar masuk, penghawaan dan pencahayaan.

\section{Kolom}

Kolom interior terdapat enam buah dan digunakan sebagai penyangga pada atap sandar atau datar area teras. Material kolom ini adalah kayu yang pada bagian atas kolom terdapat ornament. Kolom ini juga berfungsi sebagai kolom pada pagar yang ada di area teras ini. 


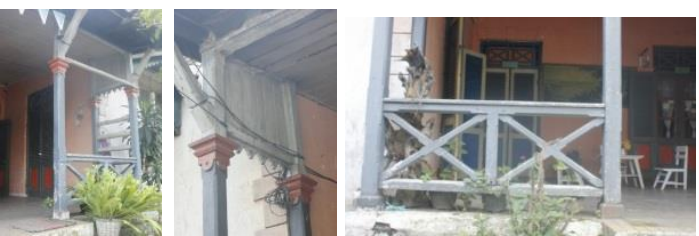

Gambar 20. Kolom pada Rumah Dinas

Kolom ini sebagai penanda pintu masuk utama bangunan. Kolom yang berada pada bagian bagian depan berbentuk persegi dengan hiasan berbentuk list kayu yang berpola semakin mengecil pada bagian bawahnya.

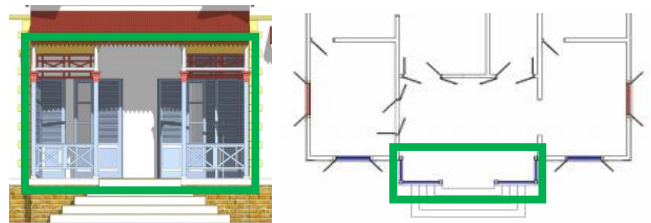

Gambar 21. Letak Kolom pada Rumah Dinas

\section{Lantai}

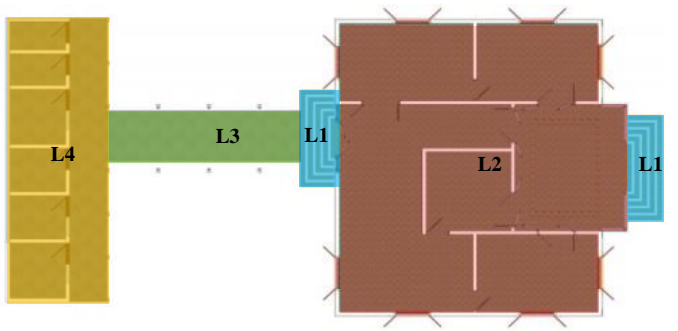

Gambar 22. Denah Type Lantai Rumah dinas

Rumah dinas ini memiliki 4 jenis lantai yang dipergunakan pada area atau zona yang berbeda pula. L1 yang merupakan jenis lantai yang digunakan hanya pada area tangga rumah dinas.
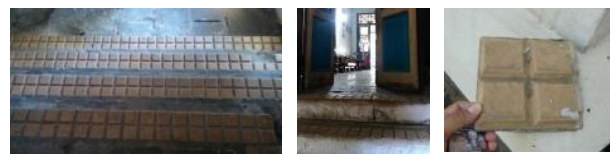

Gambar 22. Lantai L1

Kemudian untuk lantai L2 merupakan lantai tegel dengan motif seperti kulit ular dengan ukuran 30 x 30 $\mathrm{cm}$, material lantai L2 ini digunakan pada bangunan utama rumah dinas, terdapat hiasan border lantai di teras rumah dinas yang bermotif berbeda dengan motif lantai L2.

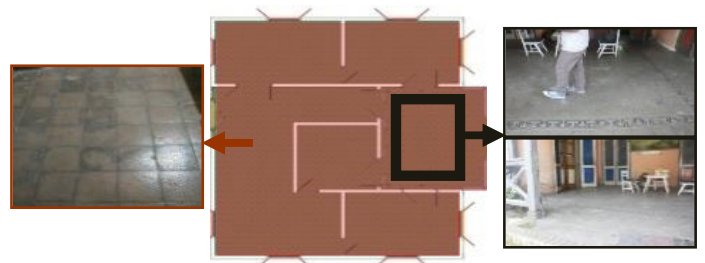

Gambar 22. Lantai L2
Sama halnya dengan lantai L2, lantai L3 yang digunakan pada selasar penghubung bangunan utama dengan bangunan service ini juga menggunakan lantai tegel, namun lantai L3 ini tidak berpola (polos) dan permukaannya lebih kasar seperti batu kali.

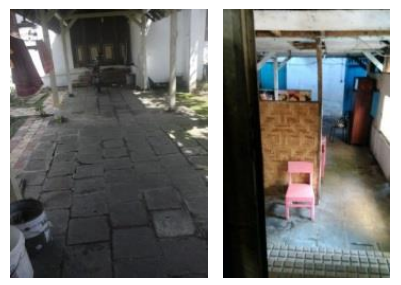

Gambar 23. Lantai L3

Dan terakhir adalah lantai L4 yang digunakan pada teras bangunan service ini juga menggunakan lantai tegel, namun lantai L4 ini tidak berpola (polos) dan permukaannya lebih halus tidak seperti lantai L3.
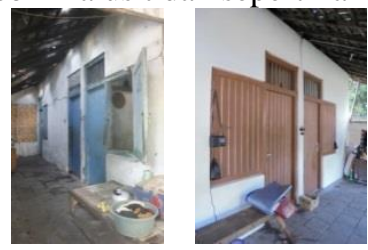

Gambar 24. Lantai L4

\section{Plafon}

Jenis plafon yang digunakan pada bangunan utama rumah dinas type 1 ini adalah jenis plafond panel kayu selebar $20 \mathrm{~cm}$ yang disusun bersebelahan dengan jarak antar panel kayunya sekitar $2 \mathrm{~cm}$.

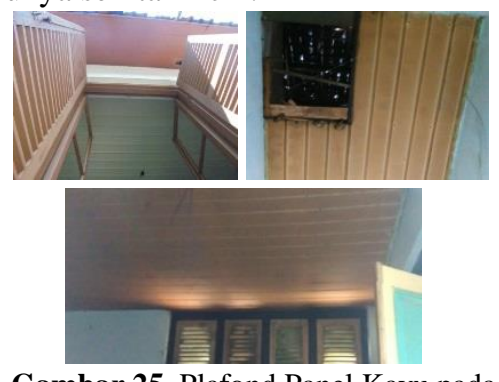

\section{Karakter struktural bangunan}

Konstruksi atap pada bangunan rumah dinas type 1 dibagi menjadi tiga macam, antara lain konstruksi atap limasan, pelana dan atap sandar / datar. Bangunan utama rumah dinas ini menggunakan atap kombinasi atap pelana pada sisi depan kanan dan kiri bangunan, konstruksi atap limasan untuk bagian kanan dan kiri bagian belakang rumah dinas serta konstruksi atap sandar / datar untuk area ruang tamu / teras dan bagian belakang kanan rumah dinas.

Untuk area selasar atau ruang penghubung dan ruang service menggunakan konstruksi atap pelana. 


\section{Metode Evaluatif}

Peninjauan pelestarian bangunan rumah dinas dilakukan dengan pengamatan terhadap kondisi eksisting dan elemen-elemen pada bangunan. Pada penjabaran studi didapatkan bahwa bangunan rumah dinas ini memiliki keterawatan bangunan yang baik. Aspek yang digunakan dalam melakukan tinjauan pelestarian antara lain, estetika (e), keterawatan (T), kelangkaan (K), keaslian (A), peranan sejarah (ps) dan keaslian bentuk $(\mathrm{Kb})$.

Tabel 1. Hasil Pengamatan Kondisi Elemen Bangunan Rumah Dinas

\begin{tabular}{|c|c|c|c|c|c|c|c|c|}
\hline No & $\begin{array}{l}\text { Variabel } \\
\text { Amatan }\end{array}$ & e & $\mathbf{T}$ & $\mathbf{K}$ & $\mathbf{A}$ & ps & $\mathbf{K b}$ & Jumlah \\
\hline 1 & \multicolumn{8}{|c|}{ Karakter Spasial } \\
\hline A & $\begin{array}{l}\text { Orientasi } \\
\text { Bangunan }\end{array}$ & 3 & 2 & 3 & 2 & 3 & 2 & 15 \\
\hline B & $\begin{array}{l}\text { Organisasi } \\
\text { Ruang }\end{array}$ & 3 & 2 & 3 & 2 & 3 & 2 & 15 \\
\hline 2 & \multicolumn{8}{|c|}{ Karakter Spasial Bangunan } \\
\hline A & $\begin{array}{l}\text { Massa } \\
\text { Bangunan }\end{array}$ & 3 & 2 & 3 & 2 & 3 & 2 & 15 \\
\hline B & $\begin{array}{l}\text { Gaya } \\
\text { Bangunan }\end{array}$ & 3 & 2 & 3 & 2 & 3 & 2 & 15 \\
\hline $\mathrm{C}$ & \multicolumn{8}{|c|}{ Elemen Fasade dan Ruang Dalam Bangunan } \\
\hline$\bullet$ & Atap & 3 & 2 & 3 & 2 & 3 & 2 & 15 \\
\hline$\bullet$ & Dinding & 3 & 2 & 3 & 2 & 3 & 2 & 15 \\
\hline$\bullet$ & \multicolumn{8}{|c|}{ Pintu dan Jendela } \\
\hline & $-\mathrm{P} 1$ & 3 & 3 & 3 & 3 & 3 & 2 & 17 \\
\hline & $-\mathrm{P} 2$ & 3 & 3 & 3 & 3 & 3 & 2 & 17 \\
\hline & $-\mathrm{P} 3$ & 3 & 2 & 3 & 2 & 3 & 2 & 15 \\
\hline & - P4 & 3 & 2 & 3 & 2 & 3 & 2 & 15 \\
\hline & - PJ & 3 & 3 & 3 & 2 & 3 & 2 & 16 \\
\hline & $-\mathrm{J} 1$ & 3 & 3 & 3 & 2 & 3 & 2 & 16 \\
\hline$\bullet$ & Kolom & 3 & 2 & 3 & 2 & 3 & 2 & 15 \\
\hline
\end{tabular}

\section{$\cdot$}

$\begin{array}{lllllll}\text { Lantai } & 3 & 3 & 3 & 3 & 3 & 2\end{array}$

- $\quad$ Langit -

Langit

$\begin{array}{llllll}3 & 2 & 3 & 2 & 3 & 2\end{array}$

17

15

3 Karakter Struktural Bangunan

- Rangka

Atap

$$
\begin{array}{llllll}
3 & 3 & 3 & 2 & 3 & 2
\end{array}
$$

16

\section{Metode Development}

Hasil dari pengamatan elemen bangunan rumah dinas menghasilkan klasifikasi potensial pada elemenelemen bangunan berdasarkan pada nilai makna kultural yang terdapat pada masing-masing tingkatan. Hasil klasifikasi menunjukkan tingkat prioritas pada elemenelemen bangunan serta menentukan tindakan pelestarian fisik berupa arahan pelestarian.

Tabel 2. Arahan Fisik Pelestarian Berdasarkan Nilai Hasil Pengamatan

\begin{tabular}{clccc}
\hline No & $\begin{array}{l}\text { Variabel } \\
\text { Amatan }\end{array}$ & Total & Kelas & $\begin{array}{c}\text { Tindakan } \\
\text { Pelestarian }\end{array}$ \\
\hline $\mathbf{1}$ & \multicolumn{2}{l}{ Karakter Spasial } & & \\
& Orientasi & 15 & Potensial & Preservasi \\
A & Bangunan & & Sedang & \\
& Organisasi & \multirow{2}{*}{15} & Potensial & Konservasi \\
B & Ruang & & Sedang &
\end{tabular}

\section{Karakter Spasial Bangunan}

\begin{tabular}{|c|c|c|c|c|}
\hline A & $\begin{array}{l}\text { Massa } \\
\text { Bangunan }\end{array}$ & 15 & $\begin{array}{c}\text { Potensial } \\
\text { Sedang }\end{array}$ & Konservasi \\
\hline B & $\begin{array}{l}\text { Gaya } \\
\text { Bangunan }\end{array}$ & 15 & $\begin{array}{c}\text { Potensial } \\
\text { Sedang }\end{array}$ & Preservasi \\
\hline $\mathrm{C}$ & \multicolumn{4}{|c|}{ Elemen Fasade dan Ruang Dalam Bangunan } \\
\hline$\bullet$ & Atap & 15 & $\begin{array}{c}\text { Potensial } \\
\text { Sedang }\end{array}$ & Konservasi \\
\hline • & Dinding & 15 & $\begin{array}{c}\text { Potensial } \\
\text { Sedang }\end{array}$ & Konservasi \\
\hline
\end{tabular}

- $\quad$ Pintu dan Jendela

$\begin{array}{cccc}\text { - P1 } & 17 & \begin{array}{c}\text { Potensial } \\ \text { Tinggi }\end{array} & \text { Konservasi } \\ \text { - P2 } & 17 & \begin{array}{c}\text { Potensial } \\ \text { Tinggi }\end{array} & \text { Konservasi } \\ \text { - P3 } & 15 & \begin{array}{c}\text { Potensial } \\ \text { Sedang }\end{array} & \text { Konservasi } \\ & & \begin{array}{l}\text { Sed } \\ \text { Ping }\end{array}\end{array}$




\begin{tabular}{llccc} 
& - P4 & 15 & $\begin{array}{c}\text { Potensial } \\
\text { Sedang }\end{array}$ & Konservasi \\
& - PJ & 16 & $\begin{array}{c}\text { Potensial } \\
\text { Tinggi }\end{array}$ & Konservasi \\
& - J1 & 16 & $\begin{array}{c}\text { Potensial } \\
\text { Tinggi }\end{array}$ & Konservasi \\
- & Kolom & 15 & $\begin{array}{c}\text { Potensial } \\
\text { Sedang }\end{array}$ & Konservasi \\
- & Lantai & 17 & $\begin{array}{c}\text { Potensial } \\
\text { Tinggi }\end{array}$ & Konservasi \\
- & $\begin{array}{l}\text { Langit - } \\
\text { 3 }\end{array}$ & $\begin{array}{l}\text { Langit } \\
\text { Karakter Struktural Bangunan } \\
\text { - }\end{array}$ & $\begin{array}{l}\text { Rangka } \\
\text { Potensial }\end{array}$ & Konservasi \\
& Atap & 15 & $\begin{array}{c}\text { Potensial } \\
\text { Tinggi }\end{array}$ & Konservasi \\
\hline
\end{tabular}

Nilai potensial tinggi antara 16-18 merupakan elemen bangunan yang masih memiliki bentuk asli, berkaitan dengan peranan sejarah dan tingkat keterawatan yang baik. Tindakan preservasi dilakukan pada elemen yang masih memiliki bentuk asli, keterawatan yang baik, tidak diperbolehkan mengganti dengan material baru dan dilakukan pencegahan. Elemen yang memiliki kerusakan namun memiliki potensi yang tinggi dilakukan tindakan konservasi. Tindakan konservasi merupakan tindakan perbaikan bagian yang rusak sesuai dengan bentuk, material, ukuran dan warna asli elemen tersebut.

Tabel 3. Arahan Fisik Pelestarian Berdasarkan Nilai Potensial Tinggi

\begin{tabular}{|c|c|c|c|c|}
\hline No & $\begin{array}{l}\text { Variabel } \\
\text { Amatan }\end{array}$ & Total & Kelas & $\begin{array}{c}\text { Tindakan } \\
\text { Pelestarian }\end{array}$ \\
\hline$\bullet$ & \multicolumn{4}{|c|}{ Pintu dan Jendela } \\
\hline & $-\mathrm{P} 1$ & 17 & $\begin{array}{c}\text { Potensial } \\
\text { Tinggi }\end{array}$ & Konservasi \\
\hline & $-\mathrm{P} 2$ & 17 & $\begin{array}{c}\text { Potensial } \\
\text { Tinggi }\end{array}$ & Konservasi \\
\hline & - PJ & 16 & $\begin{array}{c}\text { Potensial } \\
\text { Tinggi }\end{array}$ & Konservasi \\
\hline & $-\mathrm{J} 1$ & 16 & $\begin{array}{c}\text { Potensial } \\
\text { Tinggi }\end{array}$ & Konservasi \\
\hline$\bullet$ & Lantai & 17 & $\begin{array}{c}\text { Potensial } \\
\text { Tinggi }\end{array}$ & Konservasi \\
\hline
\end{tabular}

\section{Karakter Struktural Bangunan}

$\begin{array}{ccc}\text { Rangka Atap } & 16 & \begin{array}{c}\text { Potensial } \\ \text { Tinggi }\end{array}\end{array}$

Nilai potensial sedang memiliki nilai antara 1115, masih memiliki elemen yang asli atau mengalami perubahan namun tidak merubah karakter, dan memiliki keterawatan yang rendah, diarahkan dengan tindakan pelestarian berupa konservasi dan rehabilitasi. Tindakan pelestarian ini memungkinkan untuk terjadinya intervensi kepada elemen-elemen bangunan dengan tingkat kecil atau sedang. Tindakan pelestarian pada elemen potensial rendah memungkinkan untuk adanya penggantian/perubahan bahan-bahan bangunan (material) namun, material pengganti harus sama persis dengan bahan aslinya.

Tabel 4. Arahan Fisik Pelestarian Berdasarkan Nilai Potensial Sedang

\begin{tabular}{|c|c|c|c|c|}
\hline No & $\begin{array}{l}\text { Variabel } \\
\text { Amatan }\end{array}$ & Total & Kelas & $\begin{array}{c}\text { Tindakan } \\
\text { Pelestarian }\end{array}$ \\
\hline 1 & \multicolumn{4}{|l|}{ Karakter Spasial } \\
\hline A & $\begin{array}{l}\text { Orientasi } \\
\text { Bangunan }\end{array}$ & 15 & $\begin{array}{c}\text { Potensial } \\
\text { Sedang }\end{array}$ & Preservasi \\
\hline B & $\begin{array}{l}\text { Organisasi } \\
\text { Ruang }\end{array}$ & 15 & $\begin{array}{c}\text { Potensial } \\
\text { Sedang }\end{array}$ & Konservasi \\
\hline 2 & \multicolumn{4}{|c|}{ Karakter Spasial Bangunan } \\
\hline A & $\begin{array}{l}\text { Massa } \\
\text { Bangunan }\end{array}$ & 15 & $\begin{array}{c}\text { Potensial } \\
\text { Sedang }\end{array}$ & Preservasi \\
\hline B & $\begin{array}{l}\text { Gaya } \\
\text { Bangunan }\end{array}$ & 15 & $\begin{array}{c}\text { Potensial } \\
\text { Sedang }\end{array}$ & Preservasi \\
\hline $\mathrm{C}$ & \multicolumn{4}{|c|}{ Elemen Fasade dan Ruang Dalam Bangunan } \\
\hline$\bullet$ & Atap & 15 & $\begin{array}{c}\text { Potensial } \\
\text { Sedang }\end{array}$ & Konservasi \\
\hline$\bullet$ & Dinding & 15 & $\begin{array}{c}\text { Potensial } \\
\text { Sedang }\end{array}$ & Konservasi \\
\hline$\bullet$ & \multicolumn{4}{|l|}{ Pintu dan Jendela } \\
\hline & $-\mathrm{P} 3$ & 15 & $\begin{array}{l}\text { Potensial } \\
\text { Sedang }\end{array}$ & Konservasi \\
\hline & $-\mathrm{P} 4$ & 15 & $\begin{array}{l}\text { Potensial } \\
\text { Sedang }\end{array}$ & Konservasi \\
\hline$\bullet$ & Kolom & 15 & $\begin{array}{l}\text { Potensial } \\
\text { Sedang }\end{array}$ & Konservasi \\
\hline$\bullet$ & Langit - Langit & 15 & $\begin{array}{c}\text { Potensial } \\
\text { Sedang }\end{array}$ & Konservasi \\
\hline
\end{tabular}




\section{KESIMPULAN}

Arahan pelestarian yang diusulkan pada bangunan rumah dinas PT KAI Ambarawa adalah sebagai berikut :

A. Berdasarkan analisis penilaian makna kultural bangunan ditentukan pembagian elemen bangunan sebagai berikut :

- Elemen bangunan yang termasuk kedalam klasifikasi potensial sedang dengan nilai $11-15$ sebanyak sepuluh elemen bangunan

- Elemen bangunan yang termasuk kedalam klasifikasi potensial tinggi dengan nilai $16-18$ sebanyak enam elemen

B. Arahan kebijakan pelestarian fisik bangunan

- Arahan pelestarian preservasi diarahkan pada orientasi bangunan, massa bangunan dan gaya bangunan.

- Arahan kebijakan konservasi diarahkan pada organisasi ruang, atap, dinding, pintu dan jendela, kolom, lantai dan langit-langit.

\section{DAFTAR PUSTAKA}

Antariksa (2011) Metode Pelestarian Arsitektur.

Anthony J. dan Snyder, James C. (Editor). Perencanaan Kota: 413-438. Jakarta: Erlangga.

Attoe, W. (1989) Perlindungan Benda Bersejarah. Dalam Catanese,

Handinoto. (1996) Perkembangan Kota dan Arsitektur Kolonial Belanda di Surabaya (1870- 1940). Surabaya: Lembaga Penelitian dan Pengabdian Kepada Masyarakat Universitas Kristen PETRA Surabaya.

Kerr, R.J. (1982) The Conservation Plan: A Guide to the Preparation of Conservation Plans for European Cultural Significant. New South Wales: The National Trust of Australia.

Nurmala. (2003) Panduan Pelestarian Bangunan Bersejarah di Kawasan Pecinan-Pasar Baru Bandung. Tesis. Tidak dipublikasikan. Bandung: ITB

Suptandar, J.Pamudji. (2001) Arsitektur "Indis"Tinggal Kenangan. Harian Kompas.(http://arsitekturindis.wordpress.com/2 001/10/1 4/arsitektur-indis-tinggal-kenangan/).

Uno. (1998) Konsep Penerapan Insentif dan Disinsentif untuk Pelestarian Bangunan. Tesis.Tidak dipublikasikan. Bandung: ITB

\section{Undang - undang dan Peraturan Pemerintah}

Undang-undang No.11 tahun 2010 tentang Benda Cagar Budaya

PP No.10 tahun 1993 tentang pelaksanaan Undangundang No 5 tahun 1992 dan Kepmendikbud No.062/U/1995, No.063/U/1995, dan No.064/U/1995
Pemerintah Nomor 40 Tahun 1994 juga Peraturan Pemerintah Nomor 31 Tahun 2005 tentang Rumah Negara

Peraturan Pemerintah (PP) No. 40 tahun 1994 Bab IX Pasal 26 ayat 2 dibaca Rumah Negara. 